\title{
The Level of Traditional Threats of Indonesia's Defense, Based on Natural Balance of Power
}

\author{
Posma Sariguna Johnson Kennedy \\ Faculty of Economics and Business \\ Indonesian Christian University (UKI), \\ Jakarta 13630, Indonesia \\ posmahutasoit@gmail.com
}

\begin{abstract}
The level of threat in this study focused on traditional threats, where the actor is a country. Although Indonesia does not have traditional enemies, but careless against traditional/external threats can be very dangerous. Even weak defenses can be the entrance to internal conflicts due to foreign influences. With a weak defense will also result in reduced state authority in international affairs, diplomacy made for the interests of the state also does not have strong strength. The balance of forces in Indonesia with border countries began to change, due to the increasing trend of defense budgets in strategic environments. This paper seeks to see how much of the traditional threat facing Indonesia in the strategic environment. This is a way of identifying threat levels as an index of Indonesia's security needs that faced by the military capabilities of countries directly by the Indonesian border. Assuming with the natural balance of power, defined as the state's accountability in raising the potential of power not only seen from its military capabilities but also its economy. The built system is expected to create a peaceful economic rivalry and not a military conflict between countries. The threat level will be proxies by the relative military capabilities that vary across countries. In accordance with the concept of the natural balance of power, the asymmetrical balance of militarization of a country is a potential threat faced by other countries. The Global Military Index can be used, is an index describing the capacity of a weapon or militarization level in a country. The results of this study indicate that the level of threat facing Indonesia tends to increase, and the countries in strategic environments are increasing their military strength.
\end{abstract}

Keywords-Defense Economics, Traditional Threats, Natural Balance of Power, Global Military Index, Security Need Index.

\section{INTRODUCTION}

In classical or traditional thinking, the threat is always emphasized in the "country". The state becomes the target of a threat. Security functions is given in an attempt to protect the country. It is seen from the function of each security institutions, the army, police and intelligence, that gives emphasis on the state security. The threat level in this study focused on traditional threats.

Indonesia has a strategic position and very important traffic's, located between the continents of Asia and Australia, and the Pacific Ocean and the Indian Ocean. Indonesian region is bordered by ten countries, both land and sea. Indonesian land area directly adjacent to Malaysia in Borneo and Papua New Guinea in Papua. The continental border region spread over three islands, four provinces and 15 districts/cities that each region has the characteristics of different border areas. Indonesian sea areas are bordered by 10 countries, namely India, Malaysia, Singapore, Thailand, Vietnam, Philippines, Republic of Palau, Australia, East Timor and Papua New Guinea.

Although Indonesia does not have a traditional enemy, but careless against traditional/external threats can be very dangerous. Even weak defense could be the entrance of internal conflicts as a result of foreign influence. With weak defense will also result in a reduction of the authority of the state in international affairs, diplomacy that conducted for the benefit of the state also does not have a strong power.

Based on this view, national borders play an important role in determining the existence of a state. State is prepared to do anything to protect the area and the possibility of security threats that need to support a strong military.[1] In this paper we want to know the level of threat faced by Indonesia against countries in the strategic environment.

\section{REVIEW OF LITERATURE}

Virmani [2] states that since the completion of World War II, the world is changing dramatically, so the concept of "balance of power" gradually changed to "natural balance of power" in which based by the economic scale. The balance of power will also be called "stable balance" if it shows a natural balance. Natural balance of power is defined as the responsible attitude of a country in increasing the potential power in proportion to their relative attention to internationalization and global rights. The system that built is expected to create a peaceful economic competition between countries.

The difference in the balance of power between the state, can give the perception of a threat to the weaker. Lebovic and Ishaq [3] defines a threatening situation, is the asymmetric distribution of power among countries that creates a threatening condition and tension or escalation between them. 
Thus threatening situation can be expressed as the concept of relative strength. But the asymmetrical shape of this power has varying views, depend on what the underlying motives of this condition. From this perception, a country build their defense spending policies.

In forming the threat model, especially for conditions suitable for Indonesia, is to treat this as a potential threat variables or latent. This threat is not only just related to military power, but also of the physical strength of the economy that can be calculated. Leboviq \& Ishaq (1987) writes that the model is suitable for analyzing this threat, by looking at the relative military capability of a country to other countries weighted by the physical quality of the macro indicators of a country. Countries with good economy certainly will be able to buy good weapons, improving human resources and develop cutting-edge technology.

\section{ReSEARCH MethodS}

The threat level has a very abstract concept, because of it, we can form in an index. It is still very difficult to quantitatively determine the level of threat. Inspired Leboviq and Ishaq [3] which states have fundamental threat comes from external basic security needs, then the index of threat is translated to the need for security or security need index (SNI).

The threat level will be proxied by relative military capabilities that vary between countries. In accordance with the concept of natural balance of power that developed at this time, the asymmetry of the balance of the militarization of a country is a potential threat faced by other countries. Global Military Index (GMI) can be used to look at this situation. GMI is an index that describes the capacity of the power level of weapons or the militarization of the tendency of an increase or decrease in a country.[4] This index is published by the International Institute for Strategic Studies (IISS). GMI can be used as a military capability, to calculate the external threats from other countries.

Potential threats or SNI of country $i$ is a function of the relative capabilities of his country, or potential threats to security needs, as reflected in its security needs. Relative capability of a country or referred to as RCI (Relative Capability), is a function of military capability (cap) relative to his opponent states (state $j$ ), namely:

$$
R C_{i}=\left(\frac{\operatorname{cap}_{i}}{\frac{\sum\left(c a p_{j} / g e o g_{i j}\right)}{n-1}}\right)
$$

Thus SNI (security neds index) can be proxied by the way:

$$
S N I_{i}=\left(\frac{\sum\left(R C_{j} / \operatorname{geog}_{i j}\right)}{n-1}\right)
$$

In this study, a strategic environmental threat facing Indonesia is restricted to count towards the neighboring countries at the border. Where geog is the distance between the capital of two states, $(n-1)$ is the number of states in the strategic environment, and military capabilities is reflected in the magnitude of its Global Military Index.

\section{INDONESIAN TRADITIONAL THREAT}

Fundamental threats to national security, are seen from potential effect of defence development policy of their neighbor countries. Potential threat from surrounding countries of Indonesia is dealing with the strategic environment, that needs to be calculated as the Indonesian relative capabilities. GMI is an index that can be proxied relative capability of a nation. In the graph below, will be seen GMI from countries in Indonesia's strategic environment over the last fifteen years:

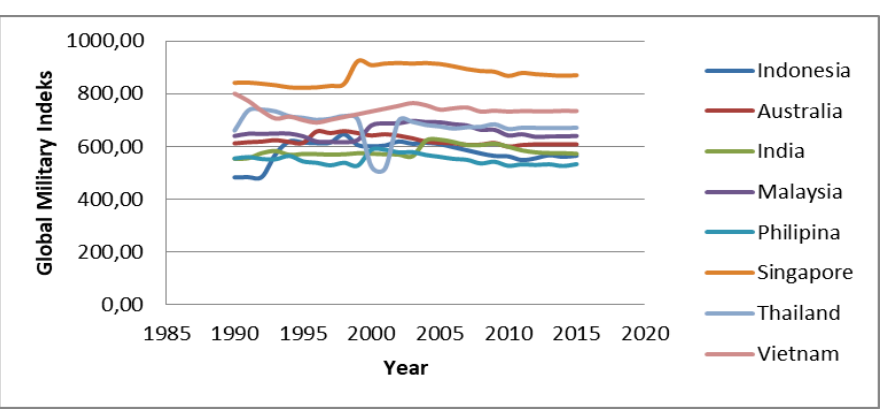

Fig. 1. The GMI of Indonesia and Neighboring Countries [5]

Based on the method of calculation of the relative capabilities from Leboviq and Isaac [3], can be formed an index of relative capability (RC) of each country that bordering Indonesia. From the country's RC, we can form SNI. RC of the countries in the border regions of Indonesia, can be seen in the graph below:

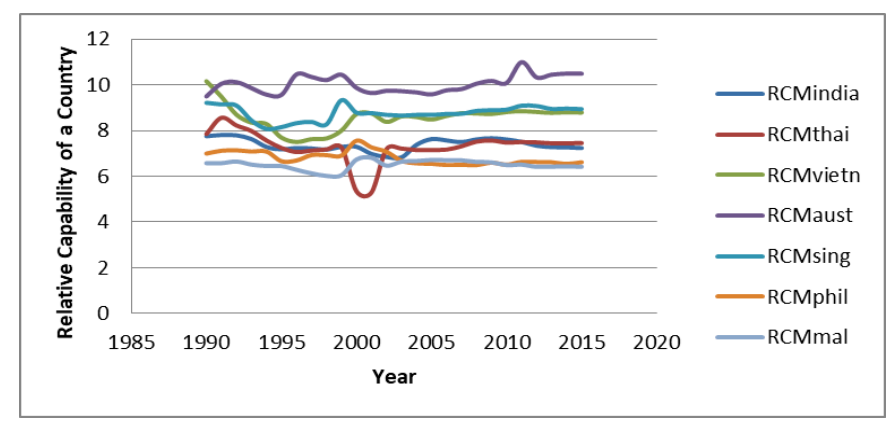

Source: IISS [5] and WDI[6]

Fig. 2. Relative Capability of a Country 
Indonesian security need index (SNI) or the Indonesian threat level is illustrated by the graph as following figure:

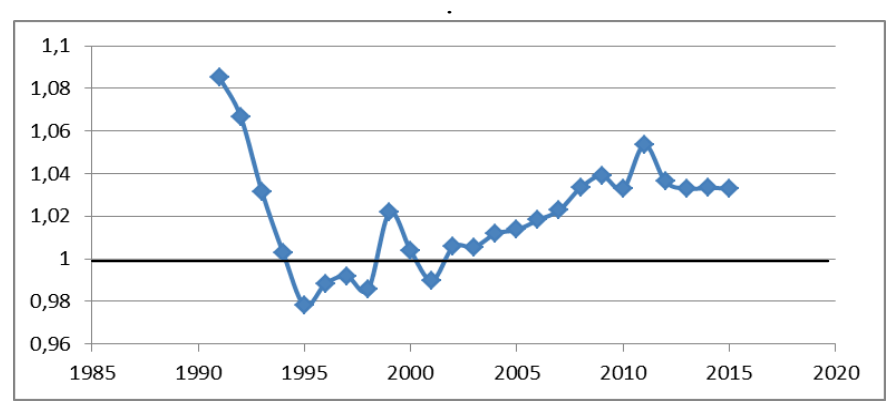

Note: No data available for Papua New Guinea, East Timor, Palau Islands, and Darwin. Source: Data Processing.

Fig. 3. Threats Faced by Indonesia (Security Need Index)

From the picture above, Indonesia in the Orde Baru era are relatively safe from external threats, but since 1995 level of Indonesian threat was increased. Even in 1998-1999 at the height of the financial crisis, the average strength of the strategic environment is larger than the Indonesian military forces. At that time the government still focused to the crisis programs. This led to the national defense program to decline. In the reformasi era, can be seen that after 2002, the potential threat from the strategic environment increased slightly larger than the Indonesian military forces.

\section{CONCLUSION}

Based on traditional threat, Indonesian security need index of the countries in the strategic environment show a rising trend. Since 2002, the countries of Indonesia's strategic environment has increasing their militarization level. All the figures show, traditional threats become serious problem for Indonesia, especially security disturbances often occur in the border region. Potential and real loss for this may have been larger than build a strong defense to keep the territorial sea, air and land in Indonesia. One of the reasons why Indonesia can not overcome this security due to the limited funds.

\section{REFERENCES}

[1] Wuryawandari, Ganewati, (The Development of Border Area Toward a Comprehensive Security) "Pembangunan Wilayah Perbatasan Menuju Keamanan Komprehensif", Jurnal Masyarakat Indonesia LIPI, (Edition XXXV, No.2) 2009, p..207.

[2] Virmani, Arvind, "Economic Performance, Power Potential and Global Governance: Towards a New International Order", ICRIER Working Paper Series, 2004.

[3] Leboviq, James H. \& Ishaq, Ashfaq, "Military Burden, Security Needs, and Economic Growth in the Middle East," The Journal of Conflict Resolution (Vol.31, No.1) 1987, pp.106-138.
[4] Grebe, Jan, "The Global Military Index," Occasional Paper of Bonn International Center for Conversion, February 2011.

[5] Institute for Strategic International Studies [Online]. Avalaible: https://www.iiss.org/.

[6] World Development Indicator. [Online]. Avalaible: https://data.worldbank.org/indicator. 